\title{
Migration and Local Development: The Multiplier Effect of Migrant Remittances on Non-recipient Households in Tsholotsho, Zimbabwe
}

DOI: https://doi.org/10.11567/met.33.2.2

UDK: 314.74:339.727](689.1)

Izvorni znanstveni rad

Primljeno: 08.11.2016.

Prihvaćeno: 09.08.2017.

\section{Divane Nzima}

Department of Sociology and Anthropology, Faculty of Social Sciences and Humanities, University of Fort Hare, Alice

dnzima@gmail.com

Vusumzi Duma

Department of Sociology and Anthropology, Faculty of Social Sciences and Humanities, University of Fort Hare, Alice

vduma@ufh.ac.za

\section{Philani Moyo}

Department of Sociology and Anthropology, Faculty of Social Sciences and Humanities, University of Fort Hare, Alice

pmoyo@ufh.ac.za

\section{SUMMARY}

Substantial policy and academic research on migration has focussed on migrant remittances to developing countries. That research has often given a positive evaluation of the impact of remittances on development, with specific reference to recipient households. However, there is limited research examining the indirect effect of migrant remittances on the development emanating from the activities of non-recipient households. Given the research gap, this paper seeks to examine the extent to which non-recipient households benefit from the flow of income and other material goods into their local economy. This study is based on a questionnaire survey ( $\mathrm{N}$ = 159) and 15 semi-structured interviews. A key finding was that remittances have partly motivated the emergence of an entrepreneurial spirit in the local economy, with most of the local small businesses (including general dealer stores, bed and breakfast accommodation, construction companies etc.) run by non-recipient households. Non-recipient households have emerged as key entrepreneurial players in response to a high consumption demand amongst the recipient households. Profits generated through these small businesses are thus satisfying the basic needs of nonrecipient households. Furthermore, a number of community projects are being financed through remittance income. These projects include food gardens, fishing and livestock farming which benefit both the recipient and non-recipient households.

KEY WORDS: migration, development, multiplier effect, remittances, Tsholotsho 


\section{INTRODUCTION}

The era of rapid globalisation that is upon us has been characterised by high levels of migration between countries. As a result, the use of the words "migration" and "development" in the same sentence is now a prominent feature in policy and academic debates. Migration has increasingly been seen as presenting opportunities for poor people from migrant-sending countries to improve their livelihood situations. According to Taylor (1999: 64): "[...] migration decisions are part of family strategies to raise income, obtain funds to invest in new activities, and insure against income and production risks [...] remittances, in some cases, simply the potential for remittances, consequently set in motion a development dynamic by loosening production and investment constraints faced by households in poor developing country environments."

Taylor echoes the tenets of the New Economics for Labour Migration (NELM), a migration theory that was popularised by Oded Stark and David Bloom in the 1980s and 1990s (Stark and Bloom, 1985; Stark, 1991). Given the above arguments, one could determine that to a reasonable extent, the benefits of migration can be accrued through migrant remittances. These remittances are predominantly used for different socio-economic, cultural and entertainment activities by the remittance-receiving households (Nzima, Duma and Moyo, 2016a). As postulated by the NELM theory, remittances and sometimes the mere potential of remittance inflows, prompt a development dynamic in the local economy (Taylor, 1999; Cassarino, 2004; Nzima, Duma and Moyo, 2016b). It can then be argued that this development dynamic benefits not only the direct recipients of remittances, but also the non-recipient members of the community. In other words, remittances have a multiplier-effect in the sense that non-recipient households benefit indirectly from the remittance flows within the local economy. However, to date there is limited research that attempts to understand whether and how migrant remittances could also benefit households that do not receive any direct remittances in Zimbabwe. In other words, the multiplier-effect of remittances has not been given the attention it deserves. Given this empirical gap, this paper seeks to examine the extent to which non-recipient households in Tsholotsho benefit from the inflow of income and other material goods into their local economy. In so doing, it specifically answers the following research questions:

- How do entrepreneurial non-recipient households take advantage of a high consumption demand triggered by remittance inflows into the local economy? 
- To what extent do community projects financed by remittances improve the livelihoods of all community members, including nonrecipient households?

- To what extent do migrant remittance inflows create employment opportunities within the local economy?

In the next sections of this paper we will discuss: (1) the context of migration and remittances in Tsholotsho, (2) the conceptual framework of this study, (3) the review of literature, (4) the methodology and methods outline, (6) the findings and discussions with regards to the multiplier effect in Tsholotsho.

\section{TSHOLOTSHO AND MIGRANT REMITTANCES IN CONTEXT}

Tsholotsho is one of the rural Districts of Zimbabwe that is well-known for its long history and culture of migration. Several factors have contributed to this well-grounded culture of migration in Tsholotsho. These include the spatial location of Tsholotsho in the southern parts of Zimbabwe which places the district in close proximity to the Botswana and South African borders. In addition, Zimbabwe's economic challenges emanating from the Structural Adjustment Programs (SAPs) in the 1990s and the economic downturn which has begun in 2000 and resulted in the near "economic collapse" in 2008 have vastly contributed to a high exodus from Tsholotsho to neighbouring countries.

According to the Solidarity Peace Trust (SPT) (2009), almost $87 \%$ of the families from this area have at least one member working in the diaspora, and the majority of them work in South Africa. Young people from Tsholotsho often seek employment opportunities in South Africa and Botswana soon after completing their high-school education. In some cases, they even drop out of school and embark on a journey to Johannesburg (Maphosa, 2005; SPT, 2009). This just shows how embedded the culture of migration is from this region to countries such as South Africa.

Migrant remittances in their broad sense constitute an important livelihood asset in Tsholotsho. As a result, transnational ties are maintained through cash and in-kind remittances. Given that most people migrating from this district have low levels of education and skills and are often undocumented migrants, they generally obtain employment in the informal sector. These migrants are often concentrated in construction, farming and in the hospitality sector working as waiters and waitresses. Through the use 
of informal channels, some are able to remit part of their incomes or in-kind items such as groceries and furniture (Chimhandamba, 2009).

Tsholotsho belongs to one of the dry ecological regions in Zimbabwe. As a result, agricultural production is seldom a viable livelihood strategy as most of the farming activities rely on rainwater. Therefore, for many years that have passed, people in Tsholotsho have relied on migration as a livelihood strategy. The socio-economic development of the district is heavily dependent on the continued inflow of remittances. Given the above, this study has sought to examine how non-recipient households participate and capitalise on the continued inflow of remittances into the local economy. There is a dearth of research focussing on migrant remittances and the interaction with non-recipient households. As a result, the indirect impact of remittances on community development is often downplayed. A setting like Tsholotsho presents good opportunities for exploring this under-researched indirect impact of migrant remittances on non-recipient households.

\section{CONCEPTUAL AND THEORETICAL FRAMEWORKS}

This study was situated within the framework of the New Economics for Labour Migration (NELM) and the Sustainable Livelihoods Approach (SLA). In analysing migration, NELM acknowledges that migrants belong in social groups such as households and communities. Therefore, it is against this background that the benefits of migration are not only seen to be benefiting an individual, but they also accrue to household members and the community at large. According to Taylor (1999), NELM postulates that migrant remittances have the potential to initiate a development dynamic in the communities of origin. A development dynamic which is set in motion within the local economy stands to benefit not only the individual migrant, but also the entire community in various ways, thereby creating a multiplier effect. For the purpose of this study, the multiplier effect shall be viewed within the context where the spending of remittances by those who directly receive them from migrants allows the creation of incomes for others and stimulates economic vibrancy within the local economy, which in turn enables poor people to create livelihoods for themselves (Bradford, Turnell and Vicary, 2008). In other words, in the context of this study, we are particularly interested in the multiplier effect as it refers to the secondand third-round effects of migrant remittances within the broader context of the local economy of Tsholotsho. 
The SLA brought in a complementary effect as it is also rooted in the analysis of social groups as opposed to individuals. While NELM views migration as a livelihood strategy to diversify labour and also to self-insure against livelihood risks (De Haas, 2010), SLA recognises multiple livelihood strategies, and migration is one of them (Ellis, 2000). Using the SLA makes it easier to identify the various ways in which the multiplier effect of migrant remittances is realised. Having analysed the vulnerability context and identified the various livelihood strategies employed by poor people in Tsholotsho, it was easy to link the various livelihood strategies to the inflow of remittances within the local economy. Most livelihood strategies were a reaction to the inflow of migrant remittances and were mostly triggered by the high consumption demand amongst remittance-recipient households within the local economy. In the process of satisfying the consumer demand, non-recipient households were able to create incomes for themselves and therefore, they were in a position to create sustainable livelihoods for themselves. In the following section, a review of literature on the multiplier effect of migrant remittances will be presented.

\section{THE MULTIPLIER EFFECT:A REVIEW OF LITERATURE}

This section provides a review of existing literature with regards to the multiplier effect ensuing from migrant remittances. Existing literature has revealed that, while migrant remittances benefit recipient households, they also benefit their national and local economies (Kapur, 2003; Newland and Patrick, 2004; De Haas, 2005; Bradford, Turnell and Vicary, 2008). However, the challenge with this pool of existing literature is the reluctance to thoroughly examine the multiplier effect, as most attempts were just in passing. According to Bradford, Turnell and Vicary (2008: 2) "spending allowed by migrant remittances has a multiplier effect on local economies as funds subsequently spent create incomes for others and stimulate economic activity generally." Adding to the debate and taking a rather controversial but audible stance, De Haas (2005) argues that, contrary to the common debate that spending remittances on consumption, housing and education is unproductive, this type of spending can actually have positive multiplier effects and increase local economic activity through which the benefits of remittances also accrue to non-migrant households. Researchers have often downplayed the consumption and investment in small businesses as unproductive; however, the angle taken by De Haas (2005) shows that these claims are not accurate. 
According to Sander and Maimbo (2003), evidence from Kenya indicates that migrant remittances were found to fuel a sustained demand for local non-farm goods and services which resulted in a multiplier effect as these were provided by non-recipients. In addition, Sander and Maimbo argue that rural households tend to spend their income from remittances on domestically produced goods, thus remittances spent in rural areas have a larger multiplier effect than those spent in urban settings. To further substantiate the above point, the research done in Kosovo by Elezaj, Bislimi and Duri (2012) revealed that migrant remittances increase the disposable incomes of recipient households which in turn increases the demand for the consumption of domestically produced goods and services. Therefore, it could be argued that this raises the demand for local labour, hence presenting an opportunity for a multiplier effect (Elezaj, Bislimi and Duri, 2012).

Previous studies conducted in Zimbabwe have tended to ignore the role of remittances in achieving a multiplier effect. Those that made an attempt have often lacked depth in addressing this concept (Bloch, 2006; Bracking and Sachikonye, 2009; Maphosa, 2007). The above studies mentioned that non-recipient individuals obtained employment from remittance recipients as housemaids, herdsman or shopkeepers. These are some of the ways through which remittance flows can result in a multiplier effect. However, the studies failed to openly acknowledge the positive role played by migrant remittances in creating the much needed incomes for others who did not receive any remittances.

A more recent study done by Ncube and Gomez (2011) did make an attempt to focus on the multiplier effect. This was evidenced by the theme of the study that was termed "follow the money". According to Ncube and Gomez (2011), due to the high inflows of remittances into the local economy, both the non-recipient and recipient households establish small businesses and benefit from the increased buying power in the local economy. In addition, they revealed that young men engage in entrepreneurial activities like moulding bricks to satisfy the demand from the recipient households who use their remittances to build homes. Ncube and Gomez (2011) further reveal that many of the recipient households hire domestic labour to help with housekeeping, looking after livestock as well as farming. Some of the findings reported by Ncube and Gomez have concurred with those by Maphosa (2007). However, Maphosa (2007) did not pay adequate attention to them and did little to recognise them as a worthwhile multiplier effect resulting from the flow of remittances into the local economy. Although Ncube and Gomez (2011) have made a good attempt at acknowledging the 
multiplier effect resulting from remittance flows, more yet needs to be done to investigate this phenomenon further; therefore, the present study hopes to pay close attention to the multiplier effect of remittances.

Remittances also serve as an important source of financing with regards to community projects. This could be classified as another form of a multiplier effect, given that remittance benefits reach a wider community. According to Kapur (2003), immigrant communities have recently made efforts to pool the remittances and channel them for public purposes. Kapur (2003) draws us to an example of Hispanic immigrants across the United States who have organised themselves into hometown associations that finance public works projects and small businesses in the towns from which they have migrated. Kapur (2003) further reports that the Mexican Federal government has welcomed the initiative made by hometown associations in their bid to develop infrastructure in their communities of origin. He added that, in order to show their support, the government and local authorities matched dollar for dollar all Home town Association remittances used to improve infrastructure or establish businesses (Kapur, 2003). This is a very good move by the authorities because by showing their support, they motivate and incentivise more remittances aimed at community development and the migrants will be pleased at the fact that their efforts are being recognised.

Previous research done by Tinajero (2009) in Angola revealed that there was evidence that Angolan migrants, especially those in Portugal, made collective contributions to local development initiatives as well as charitable initiatives. Tinajero (2009) reported that most of these collective contributions were made through migrant associations. Tinajero (2009) asserts that, although Angolan migrants' commitment to collective development cooperation is weak, the food donations, educational materials, clothes and other goods that they have financed, have contributed towards development and assisting communities in Angola. Mashayekhi (2012) adds that studies have revealed that remittances can also play an important role in the response to devastating natural disasters. Mashayekhi (2012) points to the case of Haiti, where post-disaster recovery and rehabilitation were mainly supported by remittance flows. According to Ratha (2009) cited in Mashayekhi (2012: 11): “[...] Haitian diasporas have played a key role in the reconstruction and rehabilitation of Haiti [...] 300 Haitian hometown associations in the United States and Canada also donated \$ 10000 each to their communities for social projects." This evidence from Haiti is a clear indication of a bigger potential that remittances can have, especially if the efforts 
are properly coordinated. These collective contributions made by migrants are critical in achieving far-reaching community development amongst the affected communities of origin.

Some studies conducted in Zimbabwe also revealed that remittances have played a significant role in promoting community development initiatives (Maphosa, 2007; Ncube and Gomez, 2011). According to Maphosa (2007), in the past, there have been incidents where migrants have made individual contributions towards community projects such as the refurbishment of a mortuary at a local hospital, school development projects and sporting activities in Matabeleland South. Ncube and Gomez (2011) also mentioned that migrants sponsored sports teams as an initiative to keep young people occupied in Matabeleland North. Maphosa (2007) however lamented that most of these remittance contributions have often been ad hoc and lacking in coordination. He reported that Zimbabwean migrants in South Africa have well organised and established burial societies and suggested that these presented better chances for much more coordinated collective remittance initiatives to their communities of origin. According to a study conducted by Ncube and Gomez (2011), migrants in South Africa had organised a steering committee that helped in coordinating their efforts to contribute to community projects in Matabeleland North. Contrary to the findings reported by Maphosa (2007), this study revealed that migrants were able to finance community projects such as the reconstruction of a local dam and clinic in a very well-coordinated manner with the help of a steering committee (Ncube and Gomez, 2011). From the above evidence, it is apparent that remittances are crucial in promoting community development, and although some research has reported on this subject, more yet needs to be done to examine the phenomenon further.

\section{RESEARCH METHODOLOGY}

The approach followed in this study was a mixed method one. Johnson and Onwuegbuzzie (2004), argue that the mixed-methods approach enables a holistic understanding of the subject matter being researched. The above assertion is consistent with the arguments made by Feyerabend (1975: 30) when he argued the following: "[...] A scientist who wishes to maximise the empirical content of the views he holds and who wants to understand them as clearly as he possibly can, must therefore introduce other views; that is, he must adopt a pluralistic methodology [...]." 
In an attempt to understand the nexus between migration and development wherein remittances are in the centre, we adopted pluralism in methodology informed by Feyerabend's standpoint. In doing so, we utilised both the quantitative and qualitative approaches. In addition to Feyerabend's philosophical influence, we also noted that the mixed methods approach was also used by the preceding studies on migration in Zimbabwe (Maphosa, 2007; Mangunha, Bailey and Cliffe, 2009; Ncube and Gomez, 2011). What our study had in common with those preceding studies was the desire to maximise on the strengths of mixed methods. Onwuegbuzzie and Teddlie (2002) agree with us that qualitative data can have more meaning if complemented by numbers, while more precision and meaning can be achieved from numbers when combined with narratives. These are some of the strengths that we sought to benefit from.

This article was derived from the Master's dissertation of the main author (Nzima, 2013). The research study was conducted using a questionnaire survey as well as semi-structured interviews. The research respondents were household principals and key informants such as community leaders in the District of Tsholotsho in Matabeleland North. In addition, in an attempt to heed migrant perspectives, the respondents included some migrants in Johannesburg who originated from Tsholotsho. One hundred and fifty nine survey questionnaires were completed in Tsholotsho. In addition, fifteen semi-structured interviews were conducted. Five of those were key informants in Tsholotsho and ten were migrants in Johannesburg. In total, the full sample consisted of 174 respondents. The household was used as the primary unit of analysis. However, the individuals were interviewed for the qualitative aspect of the study. None the less, the attention was not swayed away from the household as the individual interview participants drew from their experiences as members of households. Due to a lack of comprehensive statistical information, we relied on the Parliament Research Department (2011: 4), which estimated the total population to be 22,191 households in Tsholotsho. Using this figure, we used the Raosoft online sample calculator wherein at the $90 \%$ confidence level we reached an ideal sample of 200. However, owing to difficult accessibility and refusal to participate, we were only able to achieve a response rate of approximately $80 \%$, setting our completed questionnaires at 159 . We used two-stage cluster sampling to identify our respondents. We then did home visits and once a respondent agreed to be interviewed, the questionnaire was handed out and completed in the presence of the main author. This helped in getting as many questionnaires as possible fully completed. The fifteen interviews 
carried out in Tsholotsho and Johannesburg were conducted in the respondents' residences. They were very helpful in ensuring that we had an insider perspective on the role of remittances. In addition, the interviews helped in gaining an understanding of the arising trends in the survey data. Due to the distinct characteristics of the desired respondents, we had to use both the purposive and snowball sampling. Having purposively found the first respondent who possessed all the desired characteristics, we had to rely on referrals in order to find other respondents with similar characteristics. For the Johannesburg-based migrants, we needed someone who was a member of a household in Tsholotsho. On the other hand, for key informants in Tsholotsho, the respondents had to be occupying an influential position in their community. For example, being an influential member of the community could mean that one is a senior council official, school teacher, religious leader or senior police official. The criteria were designed to allow the selection of people with a holistic knowledge and understanding of the people of Tsholotsho, their livelihood strategies as well as the local economy. Local traditional leaders, such the headmen, were given an opportunity to take part in this study; however, they declined the offer.

\section{THE MULTIPLIER-EFFECT OF REMITTANCES IN TSHOLOTSHO:RESULTS AND DISCUSSION}

In the preceding section we outlined the methodology employed in this study. This section will focus on the findings that this present study has reached with regards to the multiplier effect resulting from the migrant remittances flowing into the local economy of Tsholotsho.

The preceding studies have shown that migrant remittances benefit not only recipient households but also their national and local economies (Kapur, 2003; Newland and Patrick, 2004; De Haas, 2005; Bradford, Turnell and Vicary, 2008). The inflow of remittances in the local economy of Tsholotsho stimulates entrepreneurial initiatives on the part of those who are non-recipients of remittances. According to Ncube (2010), in a bid to harness the remittances flowing into the local economy, the youth in Tsholotsho could be observed taking part in projects such as brick moulding to meet the demands of remittance-recipient households who would be building better homes for themselves. Migrant remittances in Tsholotsho have inspired innovation among non-recipient families owing to the need to benefit from the financial flows that have triggered high consumer demands within the local economy of Tsholotsho. Most of the innovative residents have positioned themselves as service providers in a bid to reap the benefits of the 
financial flows in the form of migrant remittances. In this present study we have gathered evidence that supports the fact that the benefits of income from migrant remittances also extend to non-recipient households. Interview respondents were very eager and confident that migrant remittances, despite being generally used for consumption by the recipient families, present the non-recipients with the capacity to create livelihood opportunities for themselves. The results from survey respondents corroborated the above assertion.

Most of the survey participants in this study (91.2\%) acknowledged that they benefited indirectly and directly from remittances. Only $8.8 \%$ of the survey participants held a different opinion. However, $91.2 \%$ is a very high percentage and one could reasonably believe that certainly the income from remittances has a considerable multiplier effect in the rural district of Tsholotsho. According to the New Economics for Labour Migration (NELM), one of the most important ways in which development from migrant remittances could be achieved is through the multiplier effect (De Haas, 2010; Nzima, Duma and Moyo, 2016b). The above results show that undeniably, people in the rural district of Tsholotsho perceive migrant remittances as having a multiplier effect. Following from the above, migrant remittances without a doubt have a potential to set a development dynamic in the local economy of Tsholotsho. The migrant remittances present real opportunities for people to innovate towards improved living standards. Those who have determination and a very good eye for opportunities are taking advantage of these financial flows and coming up with innovative ways of harnessing these financial flows towards the improvement of their household livelihoods. While respondents showed feelings of ambivalence and were indifferent about the benefits of migrant remittances among recipient households, they were very optimistic about the subsequent indirect benefits to non-recipients.

The Tsholotsho respondents were very eager to acknowledge that migrant remittances were a key financial asset driving their local economy which would not be vibrant without them. The following interview extract sheds light:

... monies coming from South Africa are very important in Tsholotsho, many people have been surviving on them for a long time. In Zimbabwe's bad economy Tsholotsho has been sustained by people working in South Africa sending groceries and money using informal cross border transporters. (TRSR 02 ${ }^{1}, 21$ December 2012)

TRSR refers to Tsholotsho Remittance Study Respondent. This acronym was adopted to ensure anonymity. 
This shows that people in Tsholotsho are very conscious of the value of migrant remittances in their economy. In addition, they are aware that the continued flow of remittances within the local economy of Tsholotsho stands to benefit everyone (Nzima, Duma and Moyo, 2016a). This awareness is very good because it inspires agency among the Tsholotsho residents. Being conscious of the opportunities that remittances present to them will allow them to innovate and seek ways of coming up with strategies to lift themselves out of their undesirable livelihood situations. Their consciousness is an excellent starting point towards benefiting gainfully from the multiplier effect of migrant remittances. It is this awareness that is paramount in propelling agency which will see migrant remittances triumph in creating a development dynamic within the local economy of Tsholotsho.

\section{Different ways in which non-recipient households realise the multiplier-effect}

There are different ways in which people in Tsholotsho create livelihoods as a direct result of the migrant remittance flows within their local economy. Figure 1 presents some of the ways through which non-recipient household benefit from remittances through the multiplier effect in Tsholotsho.

Figure 1. Means through which non-recipients benefit from remittances

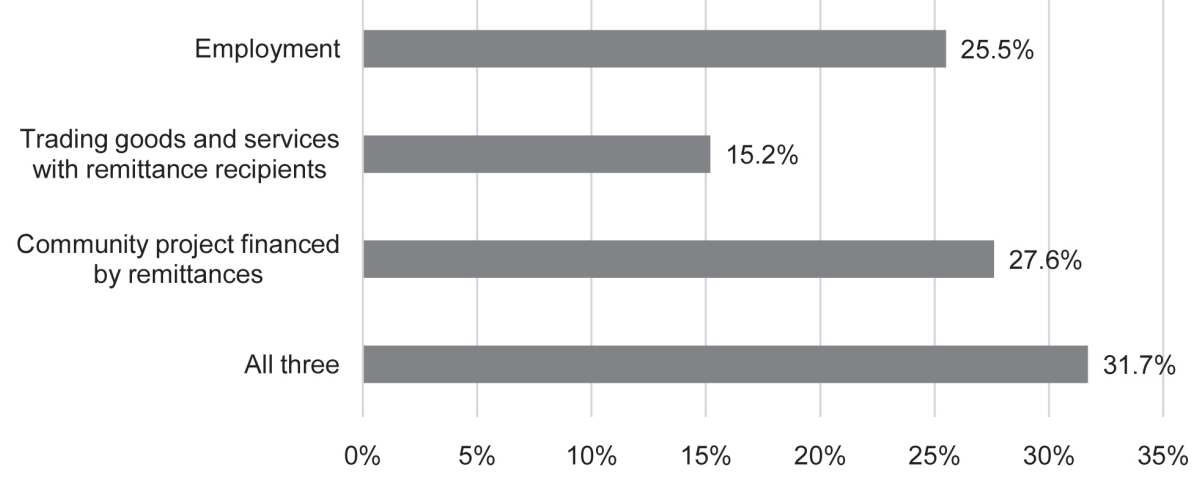

Figure 1 shows results from the 91.2\% of survey respondents who perceived migrant remittances as having a multiplier effect within the local economy of Tsholotsho. It is important to note that the $8.8 \%$ who held a different opinion are not represented in the Figure 1. All of those who ac- 
knowledged the multiplier-effect had observed various ways in which nonrecipient households had reaped the benefits from the financial flows from South Africa into Tsholotsho. From our research findings we also noticed that some people benefited in numerous ways. The figure shows that $31.7 \%$ respondents reported that people enjoyed the multiplier effect through employment, entrepreneurship as well as community projects. This indicates that people were very industrious and innovative in the bid to reap the gains of financial flows within their local economy. In the forthcoming discussions we will closely look at each form through which the multipliereffect was realised.

\section{Employment}

As could be observed from the Figure 1 above, there are many ways in which remittances reach the non-recipient households in Tsholotsho. One quarter of the survey participants $(25.5 \%)$ who acknowledged the multiplier effect reported that other people acquired employment from those with income based on migrant remittances. While some of them benefited through domestic employment, this study also came to a finding that others obtained employment from the new businesses that emerged as a result of the remittance flows into the local economy. The following excerpts highlight how non-recipient households benefit through employment in Tsholotsho:

... If you look at the trend of people who migrated to South Africa and other countries, mostly they were males and eventually you realise that even females joined in. So these people will be leaving behind children who are being taken care of by their mothers who are the children's grandparents. One way or the other these people who are at home are forced to hire housemaids or people to look after the cattle and so forth or even farming. So yes other people who do not have people sending money are directly or indirectly benefiting from these remittances. (TRSR 04, 22 December 2012)

Another respondent who is a migrant based in Johannesburg also confirmed that remittances have a multiplier effect in Tsholotsho. He reiterated that non-recipient households benefited indirectly from remittances as shown in the following interview excerpt:

... those who have businesses who work in South Africa they employ both young and old people in Tsholotsho. (JHB² 05, 05 May 2013)

JHB followed by a numerical value is an acronym chosen for the respondents in Johannesburg in a bid to ensure anonymity. 
Given the above findings, one could argue that remittances indeed have a multiplier effect through employment. Non-recipient households are able to take care of their livelihood needs owing to this multiplier effect. All they have to do is to be alert and to be able to read the trends and take the opportunities as they arise. However, the nature of employment and the income does not provide much security as most of the employment opportunities are domestic and menial. In addition, the employment relations are based on verbal contracts. Even those opportunities for employment that emerge from local businesses often lack written contracts of employment. This could pose risks such as the failure by employers to be consistent in the payment of wages, a situation that could affect the livelihoods of nonrecipient households who solely depend on the income from their jobs. On a brighter note, the multiplier effect of remittances through employment plays a great role in creating incomes for families that could otherwise have nothing to survive on. It is a fact that the wages offered by those opportunities are very low; however, without them, most of the families would be languishing in abject poverty. Previous studies have revealed that remittances have the potential to create employment (Kapur, 2003; Newland and Patrick, 2004; Nzima et al., 2017); this present study has shown that in the case of Tsholotsho, remittances certainly do create employment opportunities. In addition, Ncube and Gomez (2011) have highlighted that "following the money" without a doubt gives us a leeway in tracing the various ways (such as employment) in which remittances have a multiplier effect in the local economy.

\section{Trading goods and services}

Figure 1 illustrates that $15.2 \%$ of our survey respondents who acknowledged the presence of the multiplier effect indicated that non-recipient households enjoyed the multiplier effect of remittances in Tsholotsho through trading goods and services with remittance-recipient households. Various studies on migrant remittances have often castigated the use of remittances in what they term "unproductive consumption" (Sander, 2003; Ellis, 2003; Bloch, 2006; Turnell, Vicary and Brandford, 2008; Bracking and Sachikonye, 2009). However, De Haas (2005) argued that consumption might not be such a bad thing after all. He argued that the high consumption demand could create an enabling environment for business to flourish in the local economy. One could argue that this type of multiplier effect is mutually beneficial, given that profits generated through these small busi- 
ness initiatives are satisfying the basic needs of non-recipient households while the material needs of recipient households are catered for by the local business community. Interview respondents in the Tsholotsho case confirmed that migrant remittances had a multiplier effect since they benefit from meeting the consumption demands in the local economy, which one could argue are a resultant effect of remittance flows. The following interview extract sheds light with regards to how non-recipient households benefit:

... I might be having a shop like I do, their families use the money to buy from us and we benefit. Again, they come and buy our cattle and we also benefit that way. (TRSR 02, 21 December 2012)

Remittances have partly motivated the emergence of an entrepreneurial spirit in the local economy with most of the local small businesses (including general dealer stores, bed and breakfast accommodation, construction businesses etc.) run by non-recipient households in a bid to satisfy the high consumption demand amongst the recipient households. One of the interview respondents, a teacher in Tsholotsho, made the following remarks with regards to remittances and entrepreneurship:

... I will speak of the people taking advantage of the remittances being the people who are not actually receiving them. You will find out that most of the civil servants that are within the area, civil servants that are working in Tsholotsho, they have established bottle stores and so forth. So these are the people who have seen an opportunity and they have established shops so that they can harvest as much as they can from these remittances. (TRSR 05, 30 December 2012)

According to Bradford, Turnell and Vicary (2008: 2), "spending allowed by migrant remittances has a multiplier effect on local economies as funds subsequently spent create incomes for others and stimulate economic activity generally." The findings from the present study revealed that many non-recipient households were taking advantage of the spending power allowed by remittances in Tsholotsho. However, it is also important to note that a substantial amount of small businesses were established by households that had relatively reasonable income. Most of these were civil servants who could easily raise capital from their salaries. Poor people with absolutely no income find it difficult to establish businesses such as general dealer stores, bed and breakfast accommodation, bottle stores etc. These businesses often require more start-up capital which poor people cannot afford to raise and hence settle for businesses that require mainly their skills 
such as crafts, dress making, carpentry and informal trading or, in some instances, selling their livestock. The following interview excerpt highlights the above arguments:

... in Tsholotsho there are people who build houses, mould bricks, do dress making, some sell their crafts and there are people who do carpentry there and they make coffins so that people don't go to town to buy coffins, unless if you want one that is very very expensive or a special coffin whatever, but they do make good ones. (JHB 07, 15 May 2013)

Similar to observations made by Ncube (2010), this study also came to a finding that non-recipient households opened businesses that offered goods and services in the local economy as a bid to tap into the remittance flows in the local economy. The present study also revealed that non-recipient households also benefited from migrant remittances through selling their farm products i.e. livestock and non-farm products i.e. crafts. According to Sander and Maimbo (2003), evidence from Kenya shows that migrant remittances fuel a sustained demand for local farm and non-farm goods and services, which resulted in a multiplier effect as these were provided by the non-recipients.

\section{Community projects}

The present study also revealed that migrant remittances played a big role in financing community projects that benefited the Tsholotsho community at large. Figure 1 illustrates that $27.6 \%$ of the surveyed households who acknowledged the multiplier-effect confirmed that remittances had a multiplier effect through the community projects they finance in Tsholotsho. Previous studies have shown that migrants often organise themselves into hometown associations or steering committees to enable them to send collective remittances to finance community projects (Kapur, 2003; Tinajero, 2009; Ncube and Gomez, 2011). In the rural district of Tsholotsho, migrant remittances have assisted in financing projects such as dams, roads and philanthropic activities. Some of the findings relating to the extent of the multiplier effect of migrant remittances in the rural district of Tsholotsho could be deduced from the following interview responses:

... when we have programmes that we are carrying out, they [migrants] join hands with us. If we ask them, they are willing to assist. Even if you look within the community, most of us do not have much. In cases where most of us can only afford to contribute R10, they come in with contributions of up to R150 and this helps our development. They help because they even helped us construct 
a community dam [...] in another Ward they constructed a road and there are various projects they are involved in all over the district. (TRSR 02, 21 December 2012)

Another respondent said the following:

In some areas they really make a combined effort, for example they drill boreholes for the community, some they even assist in schools and sponsor local sporting teams. (TRSR 03, 24 December 2012)

Deducing from the above interview responses, one could argue that migrant remittances in the rural district of Tsholotsho surely benefit not only migrant families, but also the community at large. Migrants are a great asset in Tsholotsho as they help bring development to the community through the remittances they direct towards public infrastructure and philanthropic activities. In addition, it is important to note that the availability of infrastructure such as dams and boreholes has created opportunities for poor people to create food gardens. In addition, the dams and boreholes financed through migrant remittances have improved the access to drinking water for Tsholotsho residents and their livestock. This infrastructure has stretched the possibilities for sustainable livelihoods. Other people engage in fishing in the dams as a source of food. Therefore, one could argue that this development produces livelihood spinoffs which include income as well as food security for many poor households who receive no remittances. Previous remittance studies conducted in Zimbabwe did not dwell much on the multiplier effect of remittances (Bloch, 2006; Maphosa, 2007; Bracking and Sachikonye, 2009). The present study has come to a finding that migrant remittances undeniably have a multiplier effect. The study conducted by Ncube and Gomez (2011) made an attempt to focus on the multiplier effect with its theme dubbed "follow the money". In line with the findings made by Ncube and Gomez (2011), this study found that although remittances were largely spent on consumption, they brought economic vibrancy to the local economy and they benefited a lot of people through the multiplier effect that they have in the form of employment, informal trading, youth projects as well as public infrastructure. Therefore, one could argue that migrant remittances are bringing about community development in the rural district of Tsholotsho, which ensures that poor people have access to income as well as public infrastructure. These elements are very crucial preconditions in the creation of sustainable livelihoods (Nzima et al., 2017). 


\section{CONCLUSION}

This study has come to a conclusion that non-migrant families benefited in many different ways from the migrant remittance inflows. For instance, the migrant remittance inflow provides migrant families with high purchasing power. As a resultant effect, there are high consumption demands in the local economy, a situation that is ripe for entrepreneurial development. Non-migrant families have taken advantage of those high consumer demands and established small businesses through which they provide goods and services to meet the high consumer demands from remittancerecipient households. The non-recipient households could be observed running businesses such as restaurants, bed and breakfast services, general dealer stores, bottle stores as well as providing construction services. One could therefore conclude that migrant remittances have a multiplier effect in the rural district of Tsholotsho to the extent that they influence entrepreneurial development owing to the high consumer demands they trigger within the local economy. In the end, the non-recipient households who engage in the aforementioned entrepreneurial activities create sustainable livelihoods for themselves.

In addition, the study has established that in the rural district of Tsholotsho, migrant remittances have a multiplier effect to the extent that members of non-recipient households obtain employment from migrants' families. It was revealed that many people sustained their households with the income they earned working as domestic workers, herdsmen as well as custodians of homesteads. In that way, many families were able to improve the standards of living through the multiplier effect of migrant worker remittances.

Moreover, the results of this study have shown that migrant remittances have played a role in the development of public infrastructure, which benefits all community members. They have also revealed that migrants from Tsholotsho have adopted this philanthropic culture, too, and have since participated in the construction of dams, roads and contributed to philanthropic activities such as sponsoring sporting activities. One could argue that the community projects funded by income from migrant remittances create an enabling environment for community members to create livelihoods for themselves. For example, others have started agricultural projects and use the dam for irrigation purposes. This could be a very sustainable means of earning a livelihood. Therefore, it makes sense to conclude that the multiplier effect resulting from migrant remittances is far-reaching to an extent that it reduces people's vulnerability to poverty and expands their 
choices of livelihood strategies to allow for the creation of sustainable livelihoods.

\section{REFERENCES}

Bloch, A. (2006). Emigration from Zimbabwe: Migrant perspective, Solid Policy and Administration, 40 (1): 67-87, doi: https://doi.org/10.1111/j.1467-9515.2006.00477.x

Bracking, S. and Sachikonye, L. (2009). Remittances, poverty reduction and the informalisation of household wellbeing in Zimbabwe, Living on the Margins Conference, Stellenbosch, March 26-28, 2007.

Bradford, W., Turnell, S. and Vicary, A. (2008). The Remittances of Migrant Workers from Burma: An Economic Analysis of a Survey in Thailand. Naypyidaw: Burma Economic Watch.

Cassarino, J. (2004). Theorising return migration: The conceptual approach to return migrants revisited, International Journal on Multicultural Societies, 6 (2): 253-279.

Chimhandamba, N. (2009). Reconciling Formal and Informal Benefits of Remittance Channels: A Zimbabwean Migrant's Perspective (Master's thesis). Pretoria: University of Pretoria.

De Haas, H. (2005). International migration, remittances and development: myths and facts, Third World Quarterly, 26 (8): 1269-1284, doi: https://doi. org/10.1080/01436590500336757

De Haas, H. (2010). Migration and development: A theoretical perspective, International Migration Review, 44 (1):227-264, doi: https://doi.org/10.1111/j.1747-7379.2009.00804.x

Elezaj, E., Bislimi, F. and Duri, I. (2012). Kosovo remittance study, 2012, in: UNDP, July, 2012, http://www.ks.undp.org/content/dam/kosovo/docs/Remitances/KRS2012_ English_858929.pdf (26 December 2012).

Ellis F. (2000). Rural Livelihoods and Diversity in Developing Countries. Oxford: Oxford.

Ellis, F. (2003). A Livelihood Approach to Migration and Poverty Reduction. Prepared for Department for International Development (DFID).

Feyerabend, P. K. (1975). Against Method: Outline of an Anarchistic Theory of Knowledge. London: New Left Books.

Johnson, R. B. and Onwuegbuzzie, A. J. (2004). Mixed methods research: A research paradigm whose time has come, Educational Researcher, 33 (7): 14-26, doi: https://doi. org/10.3102/0013189x033007014

Kapur, D. (2003). Remittances: The new development mantra?, G-24 Technical Group Meeting, New York - Geneva: United Nations, September 15-16, 2003.

Mangunha, F., Bailey, A. and Cliffe, L. (2009). Remittance Strategies of Zimbabweans in Northern England. Leeds: University of Leeds.

Maphosa, F. (2005). The Impact of Remittances from Zimbabweans Working in South Africa on Rural Livelihoods in the Southern Districts of Zimbabwe. Johannesburg: University of the Witwatersrand (Forced Migration Working Paper Series, 14).

Maphosa, F. (2007). Remittances and development: The impact of migration to South Africa on rural livelihoods in the Southern districts of Zimbabwe, Development Southern Africa, 24 (1): 123-136, doi: https://doi.org/10.1080/03768350601165942 
Mashayekhi, M. (2012). Maximizing the development impact of remittances, in: M. Mashayekhi, L. Zhang and D. E. Vivas (eds). Maximizing the Development Impact of Remittances. New York - Geneva: United Nations, 2-24.

Ncube, G. and Gomez, G. M. (2011). Local Economic Development and Remittances in Rural Zimbabwe: Building on Sand or Solid Ground?. The Hague: International Institute of Social Studies (ISS Working Paper, 523).

Ncube, G. (2010). Migrant Remittances, Household Livelihood Strategies and Local Development: A Case Study of Village 2 in Ward 19 of Tsholotsho District in Zimbabwe (research paper submitted for a Master of Arts in Development Studies at the International Institute for Social Studies).

Nzima, D. (2013). The Developmental Role of Migrant Worker Remittances: A Case Study of Tsholotsho District in the Matabeleland North Province of Zimbabwe (Master's thesis). Alice: University of Fort Hare.

Nzima, D., Duma, V. and Moyo, P. (2016a). Migrant Remittances, Livelihoods and Investment: Evidence from Tsholotsho District in the Matabeleland North Province of Zimbabwe, Migracijske i etničke teme, 32 (1): 37-62, doi: https://doi.org/10.11567/ met.32.1.2

Nzima, D., Duma, V. and Moyo, P. (2016b). Theorizing migration-development interactions: towards an integrated approach, Migration and Development, 6 (2): 305318, doi: https://doi.org/10.1080/21632324.2016.1147897

Nzima, D., Duma, V., Moyo, P. and Hlatywayo, C. K. (2017). Local development and migrant remittances: education, skills and capabilities as preconditions for investment in Tsholotsho, Zimbabwe, Journal of Sociology and Social Anthropology, 8 (2): 69-76, doi: https://doi.org/10.1080/09766634.2017.1325152

Newland, K. and Patrick, E. (2004). Beyond Remittances: The Role of Diaspora in Poverty Reduction in Their Countries of Origin. Washington DC: Migration Policy Institute.

Onwuegbuzzie, A. J and Teddlie, C. (2002). A framework for analyzing data in mixed methods research, in: A. Tashakkori and C. Teddlie (eds). Handbook of Mixed Methods in Social and Behavioral Research. New York: Sage Publications, 351-383.

Parliament Research Department. (2011). Tsholotsho North Constituency Profile. Harare: Parliament of Zimbabwe.

Sander, C. (2003). Migration Remittances to Developing Countries. A Scoping study: Overview and Introduction to Issues for Pro-Poor Financial Service. Prepared for the UK Department of International Development (DFID).

Sander, C. and Maimbo, S. M. (2003). Migrant Labour Remittances in Africa. [New York]: World Bank (Africa Region Working Paper Series, 64).

Solidarity Peace Trust (2009). Gone to Egoli. Economic Survival Strategies in Matabeleland: A Preliminary Study. Johannesburg: Solidarity Peace Trust.

Stark, O. and Bloom, D. E. (1985). The new economics of labor migration, American Economic Review, 75: 173-178.

Stark, O. (1991). The Migration of Labor. Cambridge: Blackwell.

Taylor, J. E. (1999). The new economics of labour migration and the role of remittances in the migration process, International Migration, 37 (1): 63-88, doi: https://doi. org/10.1111/1468-2435.00066 
Tinajero, S. P. A. (2009). Angola: A Study of the Impact of Remittances from Portugal and South Africa. Geneva: International Organisation for Migration.

Turnell, S., Vicary, A. and Brandford, W. (2008). Migration Worker Remittances and Burma: An Economic Analysis of Survey Results. Naypyidaw: Burma Economic Watch. 


\title{
Migracije i lokalni razvoj: povećani učinak migrantskih doznaka na kućanstva neprimatelja u Tsholotshou u Zimbabveu
}

\author{
Divane Nzima, Vusumzi Duma, Philani Moyo
}

\author{
SAŽETAK
}

Aktualna politika i znanstvena istraživanja migracija usredotočili su se na migrantske doznake zemljama u razvoju. To je istraživanje vrlo često pozitivno ocijenilo utjecaj doznaka na razvoj, s posebnim osvrtom na kućanstva koja su primatelji. No ograničen je broj istraživanja koja ispituju neizravni učinak migrantskih doznaka na razvoj koji proizlazi iz aktivnosti kućanstava neprimatelja. S obzirom na taj jaz u istraživanju u ovom se radu pokušava istražiti koliko kućanstva koja nisu primatelji imaju koristi od protoka prihoda i drugih materijalnih dobara u svoje lokalno gospodarstvo. Ova studija temelji se na anketnom upitniku $(\mathrm{N}=159)$ i petnaest polustrukturiranih intervjua. Glavni rezultat pokazuje da su doznake djelomice pokrenule poduzetnički duh u lokalnom gospodarstvu s većinom malih lokalnih poduzeća (što obuhvaća trgovine raznom robom, smještaj s noćenjem i doručkom, građevinske tvrtke itd.) koja vode kućanstva bez primanja. Ta su se kućanstva pojavila kao glavni poduzetnički igrači u odgovoru na visoke potrošačke zahtjeve kućanstava primatelja. Na taj način dobit koju ostvaruju ta mala poduzeća zadovoljava osnovne potrebe kućanstava koja nisu primatelji doznaka. Osim toga prihodima od doznaka financira se veliki broj projekata u zajednici. Ti projekti obuhvaćaju sadnju i obrađivanje vrtova, ribolov i stočarstvo, od čega imaju koristi kućanstva koja su primatelji kao i ona koja to nisu.

KLJUČNE RIJEČI: migracije, razvoj, povećani učinak, doznake, Tsholotsho 